\title{
The Relationship Between Districts' Teacher Salary Schedule Structures and the Qualifications of Their Teacher Staffing Profile
}

\author{
Henry Tran, University of South Carolina \\ David G. Buckman, Kennesaw State University
}

\begin{abstract}
Many school administrators face difficulties hiring teachers with the requisite job credentials and qualifications. In this paper, we argue for the potential of salary structures to influence teacher staffing. Specifically, the purpose of this study is to examine whether restructuring teacher compensation salary schedules is associated with attracting larger shares of teachers with the necessary baseline qualifications for the job (i.e., "highly qualified teachers" or HQT) in a non-collective bargaining state. Fixed effects regression using panel data from 2012-2014 for 80 of South Carolina's public school districts was used to address the purpose of the study. The percent of classes not taught by HQT was found to increase as districts become more backloaded. This provides supporting evidence concerning the benefits of frontloading salary schedules. Additionally, potential drawbacks of frontloading salary schedules should be examined to improve the knowledge base of the potential costs relative to benefits of frontloading salary structures.
\end{abstract}

Keywords: teacher salary, salary schedule, pay, qualifications, retention

Over the past 30 years, the importance of educational credentials and qualifications (i.e., degrees, diplomas, certificates, and license) across all employment has increased and now serve as prominent apparatuses for job requirements in service of employee selection and screening (Isopahkala-Bouret, 2015). The problems are often exacerbated for public employees like teachers, as individuals with advanced qualifications are more likely to consider higher paying alternatives (McGinnis et al., 2016). Of interest to decision-makers is to what extent policy can ameliorate these conditions.
The problem of focus is how to increase the staffing of teacher personnel with proper qualifications. Rice et al. (2009) present several types of policy aimed at addressing teacher staffing issues, including economic incentives, avenues into the profession, hiring strategies, professional development, and working conditions. We focus on economic incentives, given that they are the most employed or recommended policy option by states and public school districts (McClure \& Reeves, 2004; National Conference of State Legislatures, 2017). Rice et al (2009) argue that even within economic incentives, there are a variety of tools that can be used to address teacher staffing such as: 1) salary schedule modifications, 2) salary enhancements, 3) limited duration incentives, 4) tuition subsidies and remission, 5) in-kind incentives and benefits, and 6) retirement benefit waivers. Salary schedule modification is the focus of this paper, and we theorize that frontloading teacher salary schedules may increase the staffing profile of appropriately qualified teachers for school employers.

The theoretical justification linking frontloaded salary schedules to teacher staffing profile is based on the argument that beginning teachers are more sensitive to pay in terms of employment decisions than seasoned teachers, both from an a recruitment and a retention perspective (Hendricks, 2015; Jacobson, 1988a; Jacobson, 1988b). This is because individuals who are just beginning their career are influenced by starting salaries when making career choices (Monk \& Jacobson, 1985). In addition, more experienced teachers are less likely to make major career and employer moves (Mark \& Anderson, 1978) and less influenced by salary when it comes to their employment retention (Murnane et al., 1987), while less experienced teachers are most vulnerable to leaving the district or profession altogether (Margolis, 2008). Given that providing larger raises earlier in the district's fixed 
rate salary schedule (i.e., frontloading) creates more competitive wages for new or early-career teachers, especially those with higher credentials and qualifications (Bó, Finan, \& Rossi, 2013), this study examines whether districts that frontload their salary schedules are associated with having more teachers with the baseline qualifications, thereby increasing the district's staffing profile of such teachers over time.

\section{Literature Review}

\section{Teacher Qualifications}

Research has consistently found that teachers are the greatest resource capable of directly impacting student learning within schools (Bowen \& Mills, 2017; Goldhaber, 2015). Therefore, to support the technical core of the school (i.e., teaching), it is imperative that the teaching force is appropriately staffed. One of the most relevant pieces of legislation that has addressed this is the No Child Left Behind (2001) (NCLB) Act, where the metric of "highly qualified teacher" (HQT) was created and all districts were mandated to employ HQT to staff their classrooms (Strunk \& Zeehandelaar, 2011). According to this legislation, to be deemed as "highly qualified," teachers must hold a bachelor's degree, have full state teaching certification, and demonstrate competency (usually through successful passage of a test) in each core academic subject taught as defined by the state. Unfortunately, teachers with these qualifications are unequally distributed in the field, with more disadvantaged students (e.g., underrepresented minorities, low income and poor academic backgrounds) more likely to be taught by teachers that are not HQT (Goldhaberet al., 2015).

Research findings have been mixed concerning the importance of the teacher qualifications highlighted in NCLB for student achievement. Some studies have suggested its importance (Darling-Hammond et al., 2005). For example, Lee (2018) analyzed a national longitudinal dataset of $7^{\text {th }}$ and $10^{\text {th }}$ grade boys and their respective teachers spanning from 1987-2007, finding that teacher level of education and teacher subject matter expertise influenced student short-term and long-term achievement. These results suggested that when controlling for other metrics of teacher quality and/or qualifications, a one standard deviation increase in cumulative teachers' level of education or cumulative teachers' subject matter expertise was positively associated with students' average mathematics increases (standard deviations of 0.032 and 0.067 , respectively). Lee also found that teacher subject-matter expertise was the only measure to remain statistically significant when controlling for all proxies of cumulative teacher quality in the study. These findings that support the importance of subject matter expertise and the possession of a bachelor's degree align with the HQT requirements.

Others have provided discounting evidence against the aforementioned qualifications. For example, when studying kindergarten student achievement gains in the area of math and reading, Guarino et al. (2006) found no significant relationship between teachers having a full certification (i.e., completed all state level certification requirements) and/or advanced degrees with student achievement in math Philips (2010) found that teachers with full or advanced certifications had less influence on student math scores as compared to those who did not hold full or advanced certifications.

Other researchers have offered partial or mixed support for subject area certification and the possession of a bachelor's degree on student achievement gains. For instance, in their study utilizing a national longitudinal data source from 1988 as well as supplemental data sources from 1990 and 1992, Goldhaber and Brewer (2000) report that there is no evidence that teachers with a standard teacher certification outperform teachers with emergency credentials. Yet when analyzing teacher degrees, they found that teachers with a bachelor's or master's degree in mathematics produced higher math student achievement scores than teachers with out-of-subject degrees, thus supporting the influence of teacher subject matter degrees and subject matter expertise on student achievement.

Although the literature has produced inconclusive results on this topic, the baseline qualifications and credentials as outlined by the HQT metric matter from a staffing perspective in the field, as they are employment requirements listed on most job advertisements. That is, they have practical significance. Therefore, this study seeks to provide evidence to guide policy that can assist hiring agents with increasing their employer's share of employees who meet the recommended minimum competency standard (i.e., bachelor's degree and state teaching license in their specific content area) for public school teaching.

\section{Backloaded and Frontloaded Salary Structures}

The traditional uniform teacher salary schedule employed by most public school districts usually pay teachers based on their experience and educational attainment (Tran, 2018). However, the traditional schedule is not uniform across all districts, and the variance within these pay structures can address specific school and district needs. For example, districts have the authority to choose the salary percentage 
increments associated with each step of the salary schedule. When analyzing teacher salary structure, Monk and Jacobson (1985) were the first to research the distribution of salary increments within school districts, and they focused on the distribution for veteran and novice teachers. They argued that pay increase premiums vary across districts and the manner in which those premiums are distributed can potentially influence teacher staffing. They conducted a longitudinal analysis spanning across a decade and found that most school districts were backloaded, which awarded larger salary premiums to veteran teachers as compared to new and/or early career teachers. Similar to Monk and Jacobson's work, other researchers (Vigdor, 2008; Lankford \& Wyckoff, 1997) found evidence of the prevalence of the common use of backloading teacher salary schedules, whereby experienced teachers were paid a higher average premium than early career teachers.

Although backloading salaries can be rewarding to veteran teachers, the frequent use of backloading teacher salary schedules can be problematic in that it may negatively influence desired school outcomes. For example, when analyzing data from a crosssectional data set from a national sample of schools in 28 states to study the influence of salary structures on student achievement, Grissom and Strunk (2012) found not only that backloading was negatively associated with the proportion of students reaching the proficiency benchmark, but also that this relationship was stable across the elementary, middle, and high school grades. Explicitly, their findings support that districts with greater relative experience premiums (i.e., higher salaries) for experienced teachers relative to beginning teachers had higher rates of students scoring below proficiency on math and reading standardized assessments. Relatedly, districts with frontloaded salary schedules (i.e., paid larger raises to teachers early in their career and smaller raises to veteran teachers) had more students who achieved and surpassed the proficiency standards across grade levels. In sum, the structure of the teacher salary schedule can have important implications for the teaching body.

\section{Empirical Framework}

\section{Procedures}

This study relies on a measure of the salary schedule structure developed by Grissom and Strunk (2012) that captures yearly teacher salary premiums at different experience levels, comparing the premium gains of veteran to beginning teachers. They explain,
The yearly returns to experience gains means the additional pay teachers receives from one year to the next to reward them for the additional year of experience accumulated. These yearly experience gains determine the slope of the salary schedule between any two years on the schedule. Our measure of salary schedule structure in effect compares the slope of the schedule late in the teaching career to the slope early in the teaching career, highlighting the degree to which districts structure salary schedules to provide premiums to veteran teachers versus novice teachers. We refer to the relative returns to experience late in the teaching career as the relative experience premium (Grissom \& Strunk, 2012, p. 670671).

Relative premium is then calculated by their formula:

$$
\text { Relative Experience Premium }=\frac{\pi^{V}-\pi^{B}}{\pi^{B}} \times 100
$$

The variable $\pi^{V}$ represents the average annual experience premiums for veteran teachers and $\pi^{B}$ represents the average annual experience premiums for beginning teachers. Higher relative experience premiums suggest that district salary schedules are more backloaded, as veteran teachers receive higher salary experience premium gains than beginning teachers. Panel data captures the fact that these returns may vary yearly.

Five years was used as the line of demarcation that distinguished veteran and beginning teachers because of several reasons. First, the bulk of prior research has suggested that the relationship between teachers' ability to improve students' academic achievement and their experience attenuates after the initial five years of teaching (Hanushek \& Rivkin, 2007; Rivkin et al., 2005). Second, teacher turnover is most prevalent within the initial five years of teaching (Hendricks, 2015; Lindqvist et al., 2014; Margolis, 2008), and this is often considered the "sorting-out phase" characterized by high mobility as compared to later phases where teachers are less likely to leave a district or the profession (Mark \& Anderson, 1978). Third, teacher tenure (which can be thought of as a symbol of the ending of a teacher's novice status) is granted by year five in most states (Grissom \& Strunk, 2012). In this study, beginning teachers were those within the first five years/steps of the teacher salary schedule, whereas veteran teachers are those within the final five years/steps of the teacher salary - 
Schedule.

Grissom and Strunk (2012) relied on the use of Schools and Staffing Survey data, and one limitation associated with this was that they were only able to observe teacher salaries for year 0,10 , and 20, whereas the present study's data included the entire spectrum of the salary schedule from minimum to maximum pay, with a focus on growth comparisons between initial and final five years of the teacher salary schedule. They were also limited to a cross-sectional set of data that does not capture changes in salary structure over time and its relationship to outcomes. This study relies on panel data analysis that mitigates these limitations.

\section{Research Question}

While teacher salary reform has been a topic that has received frequent attention in recent years by state and federal policy, "there has been relatively little empirical examination of the incentives built into salary schedules as they appear in the majority of districts today" (Grissom \& Strunk, 2012, p. 675). Past research by Jacobson (1988a) found empirical evidence linking both higher entry level salary premiums to improved ability to recruit teachers with more advanced educational training and higher salary offerings later in the salary schedule for teacher retention. However, this work focused on a specific geographic region in New York, a collective bargaining state, approximately three decades ago. Jacobson recommended that future work examine the impact of the structure of teacher salary schedules on labor market outcomes in noncollective bargaining states. To explore this, we ask to what extent does changes in districts' salary schedule structure (e.g., degree of backloading salary gains for more experienced teachers) correspond with changes in their percent of classes not taught by HQT?

\section{Analytical Strategy}

Estimates will be biased to the extent that districts' unobserved variables influence the outcomes. To mitigate this bias, panel data was used to account for fixed unobserved impacts so that estimates avoid biases from omitted time-invariant characteristics such as district culture, community support, etc. Because this study focuses on a three year time interval, it is more likely that many of these omitted characteristics would have remained stable and not have changed in any substantive manner during this time period.

Panel data allows for the capturing of not only the relationship between two variables, but also changes in that relationship across time. While this does not guarantee detection of a causal effect of the independent variable on the outcome, it does better get at such detection by addressing more confounding influences. For instance, cross-sectional analysis cannot determine whether the predictor temporally precedes the dependent variable, thereby resulting in a possible spurious relationship between the two (i.e., the relationship between the two variables is produced by a joint association with at least one other unaccounted for variable) (Mernard 1991). However, with panel data, time precedence criterion can be identified through having multiple years of data and the effects of extraneous unaccounted for variables can be better accounted for than in cross-sectional data (Finkel, 1995).

To answer the research question, the relationship between districts' percent of classes not taught by HQT and teacher salary schedule structures is examined. $Y_{\text {it }}$ represents the percent change of classes not being taught by a HQT in district $i$ at time $t$. Beyond the outcome variable, relativeexperiencepremium $m_{B A}$ it denotes the experience premium paid to veteran teachers with a bachelor's degree (BA) relative to beginning teachers with a BA. Districts with larger values of relative experience premium are more backloaded. $X_{i t}$ represents the vector of observed time-varying covariates that represent working condition factors that can influence teacher recruitment and retention. These factors include districts' poverty index (which is a composite of the percent of districts' students eligible for Medicaid services and/or qualify for free/reduced lunch), percent of students with disability other than speech, enrollment, percent of students classified as English Language Learners (ELLs), number of years the superintendent has led the district (to capture administrative consistency), student teacher ratio (a proxy for class size), and per pupil expenditures (a measure of district's capacity and/or willingness to spend). All variables besides percentages and dummies received natural logarithmic transformation for the final analysis so coefficients can be interpreted as elasticities. $W_{i}$ represents the vector of unobserved but fixed variables that may potentially contaminate the impact of frontload on $\mathrm{Y}$.

\section{Model 1:}

$Y_{\mathrm{it}}=\alpha+\beta$ 1relativeexperiencepremium $_{B A}$ it $+\beta \mathbf{X}_{\mathrm{it}}+\beta \mathbf{W}_{\mathrm{i}}+\varepsilon_{\mathrm{it}}$

To the extent that observed time-varying covariates and the unobserved fixed contaminant variables explain all effects on $Y_{\text {it }}$ beyond the effects of frontloading, the coefficient of $\beta 1$ can be seen as the effect of districts' salary schedule structure on $\mathrm{Y}$.

The second model is a replica of Model 1 with the exception of the relative experience variable, which now compares the salary premium of veteran teachers with a master's degree (MA) to beginning teachers 
with a MA.

Model 2:

$Y_{\mathrm{it}}=\alpha+\beta$ 1relativeexperiencepremium $_{M A} \mathrm{it}^{+} \beta \mathbf{X}_{\mathrm{it}}+\beta \mathbf{W}_{\mathrm{i}}+\varepsilon_{\mathrm{it}}$

\section{Sample}

The data for this study was obtained from South Carolina's department of education's public access files. Our sample consists of 80 out of the $81^{1}$ traditional public school districts in South Carolina from the years 2012 to 2014, employing and educating approximately $98 \%$ of the state's teachers and students, respectively. These specific years were intentionally selected because they are the most recent years of consecutive data available in which all the variables of interest were available and the state maintained a consistent state standardized test (the PASS test). In 2015, the test of years prior were discontinued with the transition to SCPASS, and 2016 represented a benchmark year for a new state test (South Carolina Department of Education, nd). Changing state standardized tests can alter traditional education practice, thereby influencing the attractiveness of the profession given the negative relationship between accountability pressure and teacher supply (Margolis, 2008). Additionally, state standardized tests/accountability emphasis could influence $\mathrm{W}_{\mathrm{i}}$ in ways that would threaten the internal validity of the estimate of frontload because the fixed unobservable characteristics would then vary, representing additional sources of confounding influences to the outcomes. For these reasons, the focus was on 2012 to 2014.

In addition, the state of South Carolina is beneficial to explore for several reasons. First is the issue of relevance, given that the state has been struggling with major teacher shortages. For example, there were 6,218 newly hired certificated teacher positions in 2014 -15 and about 5,280 who did not return to their teaching position that same year (Center for Educator Recruitment, Retention, \& Advancement, 2016). Furthermore, the bulk of prior state-based research on traditional teacher salary schedule structures has focused on collective bargaining states (Jacobson, 1988b; Lankford \& Wyckoff, 1997; Monk \& Jacobson, 1985; Murnane et al., 1987), where the general consensus was that districts in these states primarily backloaded their salary schedule due to union pressure that benefits veteran teachers. Recommendations were made that future research should examine traditional teacher salary structures in non-collective bargaining states (Jacobson, 1988a) to determine if patterns are different.

Supporting speculation that the degree of frontloading may differ in right-to-work states relative to collective bargaining states, the bulk of school districts in South Carolina are frontloaded (i.e., $94 \%$ for teachers with BA and MA in 2012; $90 \%$ for BA and $92 \%$ for MA in 2013; $90 \%$ for BA, and almost $94 \%$ for MA in 2014). Districts that provide equal returns to experience for veteran or beginning teachers have a relative experience premium of zero. In the data, there is only one district that fell into this category for MA.

The increased prevalence of frontloaded salary schedules compared to backloaded salary schedules found by past studies (Jacobson, 1988a; Lankford \& Wyckoff, 1997; Monk \& Jacobson, 1985; Murnane et al., 1987) may not only be a reflection of this study's focus on a Right-to-Work state, but also of the policy goal of increasing the focus on starting salaries espoused by numerous parties, including educational reformers (Vigdor, 2008). That is, the increasing prevalence of frontloaded salary schedules found in our study may not only be a reflection of the geographic context, but also the recency of the study. Districts may be increasingly frontloaded because of the benefits found to be associated with such salary schedules (Grissom \& Strunk, 2012).

Descriptive statistics for the state's school districts can be found in Table 1 . The table identifies both within- and between-district variations. As evident from the table, the dataset also includes wide variation in ranges for district variables. This is advantageous because it increases the representativeness and generalizability of the study's results. For example, the study includes a wide variation of poverty indexes for districts, ranging from districts with relatively small percentages of impoverished students $(28 \%)$ to districts with impoverished students representing the majority $(98 \%)$. In addition, the dataset includes ranges in district size from less than 1,000 students to over 70,000 enrolled.

One major criticism of past teacher salary studies is the "lack of historical information and missing measures of state policy" (Hanushek \& Rivkin, 2006, p. 1062). Because this study uses panel data, changes in salary offerings within districts can be captured. A significant Hausman test suggests that the use of a fixed effects model over a random effects model is appropriate $(p<.05)$. To account for district specific errors, robust standard errors were clustered at the district level, resulting in conservative estimates of the coefficients.

\section{Results}

The relative experience premium variable was converted to a dummy variable indicating whether a district was frontloaded (i.e., relative experience premium being $\geq 0$ ) or backloaded for Models 1 and 2 (our primary models) to assist in our determination of the 
Table 1

Descriptive Statistics for the Study Sample

\begin{tabular}{|c|c|c|c|c|c|}
\hline District Characteristics & Variation & Mean & $\begin{array}{l}\text { Standard } \\
\text { Deviation }\end{array}$ & Minimum & Maximum \\
\hline \multirow{3}{*}{$\begin{array}{l}\text { Percent of classes not taught } \\
\text { by HQT }\end{array}$} & Overall & 4.38 & 7.01 & 0 & 64.1 \\
\hline & Between & & 6.56 & 0.17 & 52.2 \\
\hline & Within & & 2.43 & -11.72 & 16.28 \\
\hline \multirow[t]{3}{*}{ BA Relative Premium } & Overall & -51.41 & 38.03 & -100 & 103 \\
\hline & Between & & 35.13 & -100 & 103 \\
\hline & Within & & 14.73 & -113.08 & 26.92 \\
\hline \multirow[t]{3}{*}{ MA Relative Premium } & Overall & -54.41 & 43.54 & -318 & 137 \\
\hline & Between & & 38.00 & -149.33 & 137 \\
\hline & Within & & 21.24 & -223.08 & 64.92 \\
\hline \multirow{3}{*}{$\begin{array}{l}\text { Teacher Salary for BA with } \\
\text { zero experience }\end{array}$} & Overall & 32234.98 & 1464.78 & 29523 & 36810 \\
\hline & Between & & 1469.44 & 29523 & 36810 \\
\hline & Within & & 140.95 & 31620.31 & 33257.31 \\
\hline \multirow{3}{*}{$\begin{array}{l}\text { Teacher Salary for MA with } \\
\text { zero experience }\end{array}$} & Overall & 36794.25 & 1635.62 & 33804 & 42371 \\
\hline & Between & & 1640.75 & 33804 & 42371 \\
\hline & Within & & 167.75 & 36090.25 & 38014.91 \\
\hline \multirow{3}{*}{ Average Teacher Salary } & Overall & 47001.37 & 2708.07 & 39821 & 53076 \\
\hline & Between & & 2647.29 & 41574 & 52325 \\
\hline & Within & & 701.56 & 44670.03 & 49395.37 \\
\hline \multirow{3}{*}{ Poverty Index } & Overall & 88.00 & 13.58 & 27.76 & 98.49 \\
\hline & Between & & 13.63 & 28.14 & 98.37 \\
\hline & Within & & 0.84 & 74.73 & 80.83 \\
\hline \multirow{3}{*}{$\begin{array}{l}\text { Percent of Students with } \\
\text { Disability (other than } \\
\text { speech) }\end{array}$} & Overall & 13.14 & 2.69 & 6.9 & 21.7 \\
\hline & Between & & 2.67 & 7.5 & 20.85 \\
\hline & Within & & 0.38 & 11.99 & 14.29 \\
\hline \multirow{3}{*}{ Enrollment } & Overall & 8817.51 & 11321.76 & 725 & 74550 \\
\hline & Between & & 11310.12 & 764.33 & 72915 \\
\hline & Within & & 298.26 & 7525.84 & 10452.51 \\
\hline \multirow{3}{*}{ Percent of ELL Students } & Overall & 18.39 & 59.41 & 0 & 756 \\
\hline & Between & & 36.06 & 0 & 263 \\
\hline & Within & & 46.94 & -243 & 511 \\
\hline \multirow{3}{*}{ Student-Teacher Ratio } & Overall & 20.89 & 3.76 & 4.35 & 29.11 \\
\hline & Between & & 3.09 & 10.83 & 25.77 \\
\hline & Within & & 2.32 & 8.26 & 27.84 \\
\hline \multirow{3}{*}{ Per Pupil Expenditure } & Overall & 9568.09 & 1935.69 & 6599 & 26289 \\
\hline & Between & & 1718.73 & 7219 & 16297.67 \\
\hline & Within & & 885.44 & 4457.42 & 19559.42 \\
\hline \multirow{3}{*}{$\begin{array}{l}\text { Superintendent's years at the } \\
\text { district }\end{array}$} & Overall & 5.53 & 4.91 & 0 & 30 \\
\hline & Between & & 4.45 & 0.5 & 23 \\
\hline & Within & & 2.09 & -3.80 & 23.20 \\
\hline
\end{tabular}


relationship between salary schedule structure and the teacher staffing profile. The results of Models 1 and 2 are displayed in Table 2.

The fixed effects model demeans all of the variables based on the within-district mean; therefore, the results suggest that the greater the increases in relative experience premium (i.e., the more backloaded districts' salary schedules), the larger the percentage of their classes not taught by HQT. Changes in the relative experience premium for teachers with a BA was statistically significant at $p<.05$ and for teachers with a MA at $p<.001$. Other statistically significant variables for Model 1 and 2 include student-teacher ratio in the expected direction (i.e., larger student teacher ratio results in larger percentage of classes not taught by HQT, as larger student teacher ratio, or larger class size is often considered an unattractive employment condition) and per pupil expenditure (which had a positive relationship with the percentage of districts' classes not taught by HQT, suggesting that districts may have to spend more to compensate for the fact the talent needs are not met- for example, through remedial programs). These results are consistent with our hypotheses and the literature.

\section{Sensitivity Analysis}

Sensitivity analyses with more conservative specifications were conducted to test the robustness of the findings. Specifically, to account for variation in geographic wage pressure within the state from differing regional labor markets (as measured by non-educator salaries for comparably educated and trained workers within each region), salaries were adjusted by the comparable wage index (Taylor, 2006).

Moreover, instead of relying on an indicator for frontloading, Models 3 and 4 relied on the actual relative experience premium as the predictor. This asks a slightly different, but related question to Models 1 and 2. The main models asked whether presence of frontloading is associated with changes in the outcome, whereas the robustness check models inquire about the extent that changes in the degree of frontloading has that relationship. As can be seen in Table 3, while the coefficients for the teacher supply variables are smaller given the change in scale, the findings were nonetheless consistent in that more frontloaded teacher salary schedules were negatively associated with the percent of classes not taught by HQT.

\section{Discussion, Implications, and Conclusion}

The findings from this study support that the qualifications of school employers' teacher staffing profiles increases as districts' frontloaded their teacher salary schedules. This builds on the literature suggesting the benefits of frontloading. For example, salary schedule premiums have been linked to student achievement. For instance, in the area of teacher performance, Tran (2017) analyzed panel data to assess the potential impact of how districts' utilized relative labor markets to set teacher salaries. He found that school districts that paid teachers according to the average market salary saw a higher percentage of students who scored proficient or above on science standardized tests than districts that paid less than the average market salary. Likewise, there have been other empirical findings that support the linkage between higher pay and higher levels of student outcomes (Grissom \& Strunk, 2012; Lin, 2010; Tran \& Buckman, 2016). As such, instituting higher pay bumps earlier in teachers' career may bring teacher salaries closer or even above the average market salary, assist in recruiting teachers with stronger qualifications, and increase student achievement.

Our study also has implications for education leaders. One of the most important tasks of the school principal is the hiring of a qualified teacher workforce (Tran, Buckman, \& Johnson, 2020). While districts across the United States, especially in high poverty regions, face challenges with teacher recruitment, they also experience dwindling funding (Black, 2016), often limiting their ability to provide financial incentives to effectively recruit new teachers. Consequently, it behooves school employers to consider how they may better repurpose existing resources to maximize their potential to hire the teachers they need. Evidence from this study provides the hiring agents, typically the school principal, an opportunity to engage with district leadership about ways to expand the recruitment pool of qualified teachers for their schools.

Like all studies, this study is not without limitations. For instance, this study focused on a specific state--South Carolina. While this was intentional because the objective, as suggested by prior research (Jacobson, 1988a), was to improve our understanding of teacher salary structures in a state where mandatory collective bargaining is not prevalent, it may restrict generalizability of the results. In addition, HQT is a minimum competency measure and may not accurately define a more effective teacher; however, it was the definition used by federal policy and still continues to have substantive implications in the field for recruitment and retention purposes. Furthermore, there has not been consensus concerning a universally accepted definition of a "quality teacher," given criticisms of the lack of reliability of measures such as value-added scores (Yeh, 2013). Also, as mentioned, the evidence base on the importance of the qualification inputs that comprise HQT for student achievement is 
Table 2

Regression Analysis for Primary Analysis

\begin{tabular}{|c|c|c|}
\hline Variables & $\begin{array}{l}\text { Percent of } \\
\text { classes not } \\
\text { taught by } \\
\text { HQT }\end{array}$ & $\begin{array}{l}\text { Percent of } \\
\text { classes } \\
\text { not taught } \\
\text { by HQT }\end{array}$ \\
\hline $\begin{array}{l}\text { Frontloaded Salary } \\
\text { Schedule for teach- } \\
\text { ers with BA }\end{array}$ & $\begin{array}{l}-0.08^{* *} \\
(0.024)\end{array}$ & \\
\hline $\begin{array}{l}\text { Frontloaded Salary } \\
\text { Schedule for teach- } \\
\text { ers with MA }\end{array}$ & & $\begin{array}{l}-0.12 * * \\
(0.04)\end{array}$ \\
\hline Poverty Index & $\begin{array}{l}0.51 \\
(0.50)\end{array}$ & $\begin{array}{l}0.81 \\
(0.51)\end{array}$ \\
\hline $\begin{array}{l}\text { Percent of Students } \\
\text { with Disability } \\
\text { (other than speech) }\end{array}$ & $\begin{array}{l}0.25 \\
(0.68)\end{array}$ & $\begin{array}{l}-0.45 \\
(0.63)\end{array}$ \\
\hline Log of Enrollment & $\begin{array}{l}-0.1 \\
(0.15)\end{array}$ & $\begin{array}{l}-0.035 \\
(0.145)\end{array}$ \\
\hline $\begin{array}{l}\text { Percent of ELL Stu- } \\
\text { dents }\end{array}$ & $\begin{array}{l}-0.009 \\
(0.015)\end{array}$ & $\begin{array}{l}0.007 \\
(0.0118)\end{array}$ \\
\hline $\begin{array}{l}\text { Log of Superinten- } \\
\text { dent's years at the } \\
\text { district }\end{array}$ & $\begin{array}{l}0.006 \\
(0.004)\end{array}$ & $\begin{array}{l}0.005 \\
(0.004)\end{array}$ \\
\hline $\begin{array}{l}\text { Log of Student- } \\
\text { Teacher Ratio }\end{array}$ & $\begin{array}{l}-0.06^{* * * *} \\
(0.016)\end{array}$ & $\begin{array}{l}-0.061^{* * *} \\
(0.15)\end{array}$ \\
\hline $\begin{array}{l}\text { Log of Per Pupil } \\
\text { Expenditure }\end{array}$ & $\begin{array}{l}0.31^{* *} \\
(0.13)\end{array}$ & $\begin{array}{l}0.28^{* *} \\
(0.127)\end{array}$ \\
\hline Constant & $\begin{array}{l}-2.14^{* *} \\
(1.132)\end{array}$ & $\begin{array}{l}-2.5^{* *} \\
(0.93)\end{array}$ \\
\hline Observations & 150 & 150 \\
\hline Imputations & 60 & 60 \\
\hline Within R-squared & 0.91 & 0.84 \\
\hline $\begin{array}{l}\text { Number of Dis- } \\
\text { tricts }^{2}\end{array}$ & 80 & 80 \\
\hline Rho & 0.98 & 0.98 \\
\hline
\end{tabular}

Note. Robust standard errors in parentheses.

**** $p<0.001,{ }^{* * *} p<0.01,{ }^{* *} p<0.05,{ }^{*} p<0.10$

${ }^{2}$ A district was removed because of missing data.
Table 3

Regression Model for Sensitivity Testing

\begin{tabular}{|c|c|c|}
\hline Variables & $\begin{array}{l}\text { Percent of } \\
\text { classes not } \\
\text { taught by } \\
\text { HQT }\end{array}$ & $\begin{array}{l}\text { Percent of } \\
\text { classes not } \\
\text { taught by } \\
\text { HQT }\end{array}$ \\
\hline Relative Experience & $0.0002^{* *}$ & \\
\hline Premium for BA & $(0.0001)$ & \\
\hline Relative Experience & & $0.0003^{* * * *}$ \\
\hline Premium for MA & & $(0.00007)$ \\
\hline Poverty Index & $\begin{array}{l}0.65 \\
(0.54)\end{array}$ & $\begin{array}{l}0.27 \\
(0.43)\end{array}$ \\
\hline $\begin{array}{l}\text { Percent of Students } \\
\text { with Disability } \\
\text { (other than speech) }\end{array}$ & $\begin{array}{l}-0.13 \\
(0.60)\end{array}$ & $\begin{array}{l}0.014 \\
(0.57)\end{array}$ \\
\hline Log of Enrollment & $\begin{array}{l}-0.094 \\
(0.15)\end{array}$ & $\begin{array}{l}-0.016 \\
(0.12)\end{array}$ \\
\hline $\begin{array}{l}\text { Percent of ELL Stu- } \\
\text { dents }\end{array}$ & $\begin{array}{l}-0.007 \\
(0.01)\end{array}$ & $\begin{array}{l}-0.006 \\
(0.01)\end{array}$ \\
\hline $\begin{array}{l}\text { Log of Superinten- } \\
\text { dent's years at the } \\
\text { district }\end{array}$ & $\begin{array}{l}0.008^{*} \\
(0.004)\end{array}$ & $\begin{array}{l}0.007^{*} \\
(0.004)\end{array}$ \\
\hline $\begin{array}{l}\text { Log of Student- } \\
\text { Teacher Ratio }\end{array}$ & $\begin{array}{l}-0.55^{\star * * *} \\
(0.015)\end{array}$ & $\begin{array}{l}-0.047^{* * * *} \\
(0.013)\end{array}$ \\
\hline $\begin{array}{l}\text { Log of Per Pupil } \\
\text { Expenditure }\end{array}$ & $\begin{array}{l}0.32^{* * *} \\
(0.11)\end{array}$ & $\begin{array}{l}0.31^{* * *} \\
(0.101)\end{array}$ \\
\hline Constant & $\begin{array}{l}-2.39 * * \\
(0.96)\end{array}$ & $\begin{array}{l}-2.73^{* * *} \\
(0.84)\end{array}$ \\
\hline Observations & 150 & 150 \\
\hline Imputations & 60 & 60 \\
\hline $\begin{array}{l}\text { Adjusted Within R- } \\
\text { squared }\end{array}$ & 0.83 & 0.83 \\
\hline $\begin{array}{l}\text { Number of Dis- } \\
\text { tricts }^{1}\end{array}$ & 80 & 80 \\
\hline Rho & 0.99 & 0.95 \\
\hline
\end{tabular}

Note. Robust standard errors in parentheses.

${ }^{* * * *} p<0.001,{ }^{* * *} p<0.01,{ }^{* *} p<0.05,{ }^{*} p<0.10$

${ }^{1} \mathrm{~A}$ district was removed because of missing data. 
mixed (Lee, 2018; Goldhaber \& Brewer, 2000). Finally, the findings of this study cannot support causal conclusions, although efforts were taken to increase the rigor of analysis to better safeguard against threats to the internal validity of the study.

Despite these limitations, this study makes important contributions to the literature on teacher compensation by advancing our knowledge of the current teacher pay structure. Beyond the benefits already mentioned, it has also been argued that frontloading teacher salary schedules will better align it with the compensation structure of professionals such as doctors and lawyers who often reap the full earning potential from their expertise within the first ten years of their career (Vigdor, 2008). This study builds on the literature that provides empirical support for such a decision. Future research should examine the potential drawbacks of frontloading salary schedules to improve the knowledge base of the potential costs relative to the benefits of frontloading salary structures.

\section{Note}

${ }^{1}$ Estimates of 1 of the school districts was not included in the final analysis because of missing data as explained in Tables 2 and 3.

\section{References}

Bó, E.D., Finan, F., \& M.A. Rossi (2013). Strengthening state capabilities: The role of financial incentives in the call to public service. Quarterly Journal of Economics, 128(3), 1169-1218.

Bowen, D., \& Mills, J.N. (2017). Changing the education workforce? The relationships between teacher quality, motivation, and performance pay. Teachers College Record, 119(4), 1-32.

Center for Educator Recruitment, Retention, \& Advancement. (2016). A report on the Fall 2015 supply and demand. http://cerra.org/media/ d $\quad$ ments/2016/1/2015_Supply_Demand_Report.pdf

Darling-Hammond, L., Holtzman, D.J., Gatlin, S.J., \& Heilig, J.V. (2005). Does teacher preparation matter? Evidence about teacher certification, Teach for America, and teacher effectiveness. Education Policy Analysis Archives, 13(42), retrieved from https://epaa.asu.edu/ojs/article/view/147/273

Finkel, S.E. (1995). Causal analysis with panel data. Thousand Oaks, CA: Sage Publishing.

Goldhaber, D. (2015). Teachers clearly matter, but finding effective teacher policies has proven challenging. In Ladd, H., \& Goertz, M. (Eds.), Handbook of Research in Education Finance and Policy (pp. 146-165). New York, NY: Routledge.
Goldhaber, D., \& Brewer, D.J. (2000). Does teacher certification matter? High school teacher certification status and student achievement. Educational evaluation and policy analysis, 22(2), 129-145.

Goldhaber, D., Lavery, L., \& Theobald, R. (2015). Uneven playing field? Assessing the teacher quality gap between advantaged and disadvantaged students. Educational Researcher, 44(5), 293-307.

Grissom, J.A., \& Strunk, K.O. (2012). How should school districts shape teacher salary schedules? Linking performance to pay structure in traditional compensation schemes. Education Policy, 26(5), 663-695.

Guarino, C.M., Hamilton, L.S., Lockwood, J.R., \& Rathburn, A.H. (2006). Teacher qualifications, instructional practices, and reading and mathematics gains of kindergarteners (NCES 2006-031). Washington, DC: U.S. Department of Education, National Center for Education Statistics.

Hanushek, E., \& Rivkin, S.G. (2007). Pay, working conditions and teacher quality. Future of Children, 17(1), 69-86.

Hanushek, E.A., \& Rivkin, S.G. (2006). Teacher Quality. In Hanushek, E.A., \& Welch, F. (Eds.), Handbook of the economics of education, 2 (pp. 1051-1078). Elsevier B.V.

Hendricks, M.D. (2015). Towards an optimal teacher salary schedule: Designing base salary to attract and retain effective teachers. Economics of Education Review, 47, 143-167.

Isopahkala-Bouret, U. (2015). Educational credentialing of an aging workforce: Uneasy conclusions. Adult Education Quarterly, 65(2), 83-99.

Jacobson, S. (1988a). Alternative practices of internal salary distribution and their effects on teacher recruitment and retention. Journal of Education Finance, 14(2), 274-284.

Jacobson, S. (1988b). The distribution of salary increments and its effect on teacher retention. Educational Administration Quarterly, 24(2), 178-199.

Lankford, H., \& Wyckoff, J. (1997). The changing structure of teacher compensation, 1970-94. Economics of Education Review, 16, 371-384.

Lee, S.W. (2018). Pulling back the curtain: Revealing the cumulative importance of high-performing, highly qualified teachers on students' educational outcome. Educational Evaluation and Policy Analysis, 40(3), 359-381.

Lin, T.C. (2010). Teacher salaries and student achievement: The case of Pennsylvania. Applied Economics Letters, 17(6), 547-550. 
Lindqvist, P., Nordanger, U.K., \& Carlsson, R. (2014). Teacher attrition the first five years - a multifaceted image. Teaching and Teacher Education, 40, 94103.

Mark, J.H., \& Anderson, B.D. (1978). Teacher survival rates: A current look. American Educational Research Journal, 15(3), 379-383.

Margolis, J. (2008). What will keep today's teachers teaching? Looking for a hook as a new career cycle emerges. Teachers College Record, 110(1), 160-194.

McClure, C., \& Reeves, C. (2004). Rural teacher recruitment and retention: Review of the research and practice literature. Nashville, TN: Appalachia Educational Laboratory.

McGinnis-Johnson, J., \& Ng, E.S. (2016). Money talks or millennials walk: The effect of compensation on nonprofit millennial workers sector-switching intentions. Review of Public Personnel Administration, 36(3), 283-305.

Mernard, S. (1991). Longitudinal research. Newbury Park: Sage Publication.

Monk, D.H., \& Jacobson, S.L. (1985). The distribution of salary increments between veteran and novice teachers: Evidence from New York State. Journal of Education Finance, 11, 157-175.

Murnane, R.J., Singer, J. \& Willett, J. (1987). Changes in teacher salaries during the 1970s: The role of school district demographics. Economics of Education Review, 6(4), 379-388.

National Conference of State Legislatures. (2017, October). Tackling teacher and principal shortages in rural areas. LegisBrief, 25(40), 1-2.

Rice, J., Roellke, C., Sparks, D., \& Kolbe, T. (2009). Piecing together the teacher policy landscape: Multi-level case study findings from three states. Teachers College Record, 111(2), 511-546.

Rivkin, S.G., Hanushek, E., \& Kain, J. (2005). Teachers, schools, and academic achievement. Econometrica, 73, 417-458.

South Carolina Department of Education. (nd). Test Dates - South Carolina Department of Education. Retrieved from https://ed.sc.gov/tests/assessmentinformation/test-dates.

Strunk, K.O., \& Zeehandelaar, D.B. (2015). Added bonus? The relationship between California school districts' specialized teacher staffing needs and the use of economic incentive policies. Educational Policy, 29(2), 283-315.

Taylor, L.L. (2006). Comparable wages, inflation and school finance equity. Education Finance and Policy, 1(3), 349-371.

Tran, H. (2018). Taking the mystery out of South Carolina school finance (2nd edition). ICPEL Publications.
Tran, H. (2017). Does the pay stance of South Carolina public school districts influence their math and science achievement scores? Journal of Education Finance, 43(2). 105-122.

Tran, H., \& Buckman, D. (2016). Pay for progress: The relationship between Florida districts' teacher salary offerings and their high school dropout rates. Journal of School Public Relations, 37(3), 320-346.

Vigdor, J. (2008). Scrap the sacrosanct salary schedule. Education Next, 8(4), 36-42.

Yeh, S.S. (2013). A Reanalysis of the Effects of Teacher Replacement Using Value-added Modeling. Teachers College Record, 115(12), 1-35.

\section{Authors}

Henry Tran, MPA, PHR, SHRM-CP, Ph.D., is an assistant professor of the Department of Educational Leadership and Policies at the University of South Carolina. He researches education human resources (HR) and strategic talent management, and is author of a book on the topic for Routlege/University Council for Educational Administration (UCEA).

David G. Buckman, Ph.D., is an Assistant Professor of Educational Leadership and Ed.S. Program Coordinator in the Department of Educational Leadership at Kennesaw State University in Kennesaw, Georgia. He studies school human resources and school finance issues in the P-12 educational environment. 